\title{
DESAIN MODEL FUZZY CONTROL UAV BERBASIS MATLAB/SIMULINK PADA ARDUINO FLIGHT CONTROLLER
}

\author{
${ }^{(1)}$ Muchamad Malik, ${ }^{(2)}$ Aan Burhanuddin \\ ${ }^{(1)}$ Prodi Teknik Mesin Universitas Proklamasi 45 Yogyakarta \\ ${ }^{(2)}$ Prodi Teknik Mesin Universitas PGRI Semarang \\ ${ }^{(1)}$ Email: m.malik@up45.ac.id \\ Jl. Proklamasi No.1 Babarsari Yogyakarta
}

\begin{abstract}
Quadrocopter is an aerial vehicle platform that has become very popular among researchers from the past because it has advantages compared to conventional helicopter. The quadrocopter design is very simple and unique, but seen from an unstable aerodynamic standpoint. From existing research, researchers have proposed many control system designs for quadrocopter. In this study the author presents a fuzzy logic controller for quadrocopter. The method in this research is by designing hardware. After that the design for fuzzy controllers. Then the designed fuzzy controller is tested in the Hardware In Loop (HIL) setting.The experimental results and validation of the controller application functions are considered satisfactory and it is concluded that it is possible to stabilize quadrocopter with fuzzy logic controller.
\end{abstract}

keywords: quaadcopter, fuzzy, control system.

\begin{abstract}
ABSTRAK
Quadrocopter merupakan platform wahana udara yang telah menjadi sangat populer di kalangan peneliti dari masa kemasa karena mempunyai keunggulan dibandingkan dengan helikopter konvensional. Desain quadrocopter sangat sederhana dan memiliki keunikan, tetapi dilihat dari sudut pandang aerodinamika tidak stabil. Dari penelitian yang sudah ada para peneliti telah mengusulkan banyak desain sistem kontrol untuk quadrocopter. Dalam penelitian ini penulis menyajikan fuzzy logic controller untuk quadrocopter. Metode dalam penelitian ini adalah dengan perancangan perangkat keras. Setelah itu desain untuk pengontrol fuzzy. Kemudian kontroler fuzzy yang dirancang diuji dalam pengaturan Hardware In Loop (HIL). Hasil percobaan dan validasi fungsi penerapan pengontrol dianggap memuaskan dan disimpulkan bahwa mungkin untuk menstabilkan quadrocopter dengan pengontrol logika fuzzy.
\end{abstract}

keywords: quaadcopter,fuzzy,system kontrol.

\section{PENDAhuluan}

Unmanned aerial vehicle (UAV) adalah pesawat terbang tanpa pilot yang dapat terbang sendiri atau dikendalikan dari jarak jauh berdasarkan program yang diunduh ke komputer. Kendaraan udara tak berawak memiliki area aplikasi yang sangat luas.

UAV pada dasarnya dapat dibagi menjadi dua kategori, UAV sayap tetap dan UAV sayap rotasi. Rotating wing (atau helikopter) UAV memiliki beberapa keunggulan dibandingkan UAV sayap tetap yang dapat lepas landas dan mendarat secara vertikal, dan juga dapat mempertahankan posisi mereka pada titik tetap. Quadrocopters memiliki beberapa keunggulan dibandingkan dengan helikopter konvensional yang dapat dikontrol dengan mengubah kecepatan rotor. Kedua, penggunaan empat rotor memungkinkan masing-masing rotor memiliki diameter yang lebih kecil daripada rotor helikopter konvensional sehingga dapat memperoleh lebih sedikit energi kinetik selama penerbangan. Keuntungan yang paling penting adalah dapat membuat manuver yang tidak dapat dilakukan oleh helikopter konvensional.

\section{TINJAUAN PUSTAKA}

Quadcopter ketika beroperasi menggunakan empat rotor dan empat buah baling-baling. Dua rotor berputar melawan arah jarum jam dan dua lainnya searah jarum jam. 
Karena kombinasi ini lah sistem mampu mengendalikan gaya angkat pesawat, melalui kondisi torsi yang seimbang. Sedangkan ketika dilihat dari segi "vertical take off and landing aircraft (VTOL)" quadcopter mampu melakukan pitch, yaw, dan roll menggunakan kontrol kendali empat rotor.

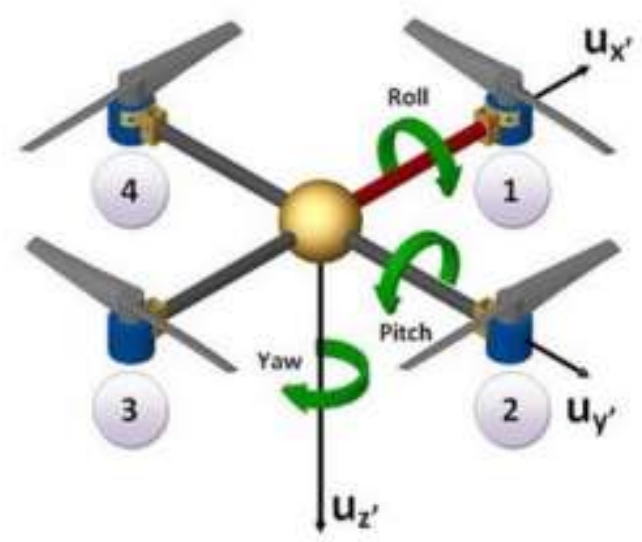

Gambar 1 Gerakan Dasar Quadcopter

Mikrokontroler digunakan sebagai prosesor utama on-board. Semua sensor akan dihubungkan dengan pengontrol ini. Pengendali membaca data sensor pada setiap iterasi kode yang program ke dalamnya. Data ini dikirim ke komputer dalam bentuk 12 byte, dua byte untuk setiap pembacaan sensor.

Motor brushless merupakan motor $\mathrm{dc}$ yang tidak hanya tiga kutub tetapi 14 , rotasi motor per $2 \pi / 3=60^{\circ}$ shift pergeseran fasa adalah $8,6^{\circ}$, yang memiliki efek yang sama dengan gear box. Motor mempunyai kecepatan 840rpm per volt sehingga cocok digunakan pada batre 3 sel LiPo yang menghasilkan tegangan total $12,6 \mathrm{~V}$ dan kecepatan putaran maksimum 10080rpm.

Sebuah sensor kompas digunakan untuk pengukuran arah dan stabilitas sumbu yaw. Untuk mendapatkan posisi heading yang tepat, digunakan sebuah modul kompas HMC6352. Honeywell HMC6352 adalah modul kompas yang menggabungkan sensor 2-axis magnetoresistive dengan sirkuit dukungan analog dan digital dan algoritma untuk komputasi perhitungan.
Kontrol hover yang stabil membutuhkan 3 sensor gyro: Pitch, Roll, dan Yaw. ADXRS300 adalah sebuah sensor analog. Mempunyai output tingkat perubahan sudut dengan rentang tegangan $\mathrm{DC}$ dari $0 \mathrm{ke} 5 \mathrm{~V}$, sesuai dengan 300 。 / detik ke +300 。 / detik, di mana 2,5V adalah sama dengan 0 . Untuk membaca data giroskopik dari ADXRS300 digunakan internal analog to digital converter (ADC) dari mikrokontroler.

Untuk terbang secara autonomous diperlukan teknik navigasi. Global Positioning System (GPS) paling sederhana dan sesuai untuk aplikasi ini adalah Modul GPS in-door LEA-5H-008. Konverter usb ke UART eksternal dibuat untuk menghubungkan modul GPS ke mikrokontroler.

Fuzzy secara harfiah berarti samar, sedangkan kebalikannya dalam hal ini adalah Crisp yang secara harfiah berarti tegas. Dalam kehidupan sehari-hari nilai samar lebih akrab daripada nilai tegas. Temperatur tertentu biasa dinyatakan sebagai panas, agak panas, atau sangat dingin daripada dinyatakan dalam nilai terukur tertentu.

Tahun 1965 L.A. Zadeh memodifikasi teori himpunan yang disebut himpunan kabur (fuzzy Set). Himpunan fuzzy di dasarkan pada gagasan untuk memperluas jangkauan fungsi karakteristik sehingga fungsi tersebut akan mencakup bilangan real pada interval $[0,1]$. Nilai keanggotaannya menunjukkan bahwa suatu nilai dalam semesta pembicaraan tidak hanya berada pada 0 atau 1 , namun juga nilai yang terletak diantaranya. Dengan kata lain nilai kebenaran suatu hal tidak hanya bernilai benar atau salah. Nilai 0 menunjukkan salah, nilai 1 menunjukkan benar dan masih ada nilai-nilai yang terletak diantaranya.

PWM (Pulse Width Modulation) digunakan untuk mengatur kecepatan dari motor DC. Dimana kecepatan motor DC tergantung pada besarnya duty cycle yang diberikan pada motor DC tersebut.Pada sinyal PWM, frekuensi sinyal konstan sedangkan 
duty cycle bervariasi dari 0\%-100\%. Dengan mengatur duty cycle akan diperoleh keluaran yang diinginkan. Sinyal PWM (Pulse Width Modulation) secara umum dapat dilihat dalam Gambar 2 berikut:

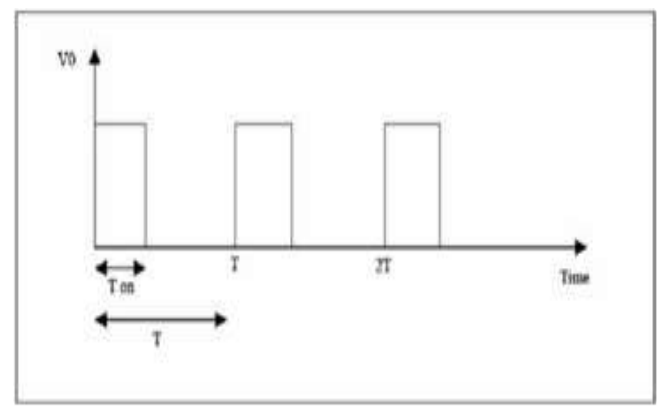

Gambar 2 Sinyal PWM

Untuk mengontrol quadrocopter, banyak skema kontrol telah diusulkan. Pengontrol umpan balik yang kuat berdasarkan teknik $\mathrm{H} \infty$, kontrol fuzzy, pengontrol PD, dan NeuralNetwork Adaptive Flight Control adalah beberapa contoh skema kontrol untuk mengendalikan quadrocopter. Untuk eksperimen yang dilakukan pada UAV, metode kontrol nonlinear dipilih yang menggunakan inversi dinamis diskrit-waktu, di bawah saturasi input. Studi lain yang dilakukan di Universitas Pennsylvania menunjukkan contoh kontrol lain, yang menggunakan metodologi kontrol berbasis visi untuk kontrol UAV.

Semua skema kontrol yang dinyatakan di atas mengharapkan para desainer untuk memiliki pemahaman yang luas tentang persamaan matematika yang mengatur dinamika quadrocopter. Untuk menghindari kompleksitas desain yang terkait dengan skema kontrol yang disebutkan di atas, kami memutuskan untuk merancang kontroler fuzzy untuk quadrocopter dan menganalisis bagaimana kinerjanya dengan quadrocopter karena belum pernah diuji pada quadrocopter.

\section{METODOLOGI}

\section{A. Desain pengontrol fuzzy quadrocopter}

Untuk merancang kontroler fuzzy, dibuat desain kontroler fuzzy untuk dua derajat kebebasan, yaitu; pitch and roll. Pengontrol fuzzy yang dikerjakan kemudian digunakan pada simulasi quadrocopter. Kemudian didesain dengan tiga input yaitu; akselerasi, kecepatan dan akumulasi perintah sebelumnya di sekitar dua sumbu horizontal X dan Y untuk mempertahankan quadrocopter dalam posisi melayang. Untuk merancang pengontrol fuzzy digunakan pendekatan sudut quadrocopter dan laju perubahan sudut sebagai input ke pengontrol fuzzy.

Pedoman untuk membuat aturan fuzzy yang dibentuk diberikan di bawah ini:

1. Kontrol quadrocopter dilakukan dengan mengamati sudut tepi dan laju perubahan sudut.

2. Hanya informasi kualitatif sudut dan tingkat perubahan sudut yang tersedia untuk pilot.

3. Kecuali dalam roll manuver aerobatic yang tinggi, kontrol pitch dan yaw kendaraan ditangani secara terpisah dan independen.

4. Ketika sudut kendaraan yang diamati kecil (mis. Dekat titik hover), lebih banyak perhatian diberikan pada sudut quadrocopter daripada laju perubahan.

5. Ketika sudut yang diamati dari quadrocopter besar, maka lebih banyak perhatian diberikan pada laju perubahan sudut dan lebih banyak upaya dilakukan untuk mengkompensasi laju dari sudut ke sudut.

6. Perintah kontrol yang dikeluarkan oleh operator manusia bisa merupakan salah satu dari empat perintah kuantitatif yaitu roll, pitch, push dan yaw.

7. Sudut yang dapat diamati dan laju perubahan sudut dipahami oleh operator manusia baik kecil, sedang atau besar. Akumulasi perintah kontrol dianggap nol, kecil, sedang, dan besar.

Kemudian mulai merancang pengontrol fuzzy untuk quadrocopter berdasarkan pedoman yang disebutkan di atas. Pedoman 1 mendefinisikan input dari pengontrol, yaitu sudut dan laju perubahan sudut. Pedoman 7 menyarankan lima fungsi keanggotaan untuk setiap input.

Penulis menggunakan bentuk segitiga atau trapesium untuk fungsi keanggotaan untuk menghindari kompleksitas komputasi dan pemrograman, karena ada rencana untuk menerjemahkan pengontrol yang dirancang ke bahasa $\mathrm{C}$ di masa mendatang.

Penulis memulai dengan distribusi fungsi keanggotaan yang seragam seperti yang ditunjukkan pada Gambar 3.

Kemudian dalam mencari kinerja yang lebih baik, penulis meningkatkan perolehan input dengan mengambil fungsi keanggotaan lebih dekat ke nol seperti yang ditunjukkan 
pada Gambar 4. Tetapi untuk pengaturan ini, penulis mendapat respons osilasi. Jadi, untuk memperbaiki osilasi dan menghindari penguatan noise, penulis mulai mengurangi input dengan memperluas fungsi keanggotaan secara bertahap. Setelah mengujian sistem dengan beberapa pengaturan fungsi keanggotaan, pengaturan fungsi keanggotaan input yang disajikan pada Gambar 5 sehingga ditemukan yang terbaik. Prosedur yang sama diulang untuk input kedua dan mendapatkan hasil terbaik pada pengaturan yang sama yang digunakan untuk input pertama.

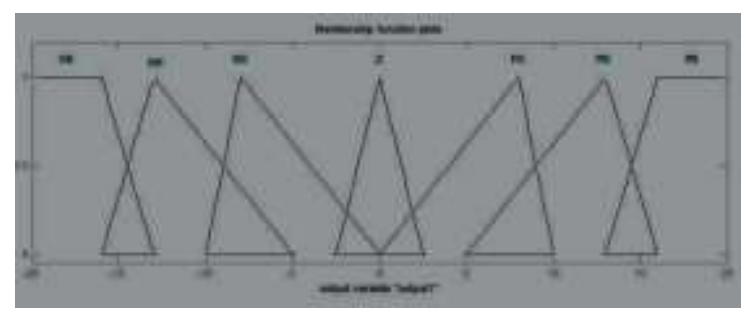

Gambar 3 Fungsi keanggotaan untuk input

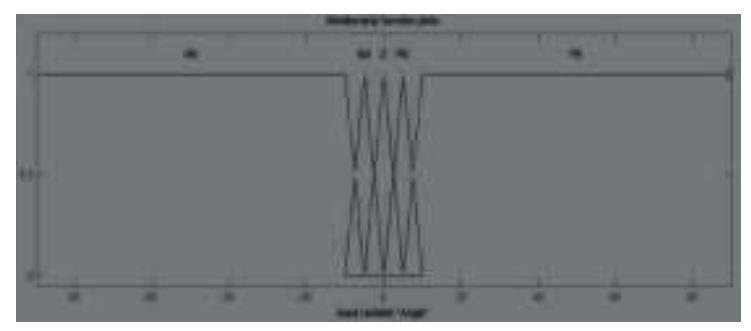

Gambar 4 variabel input sudut roll dengan input tinggi

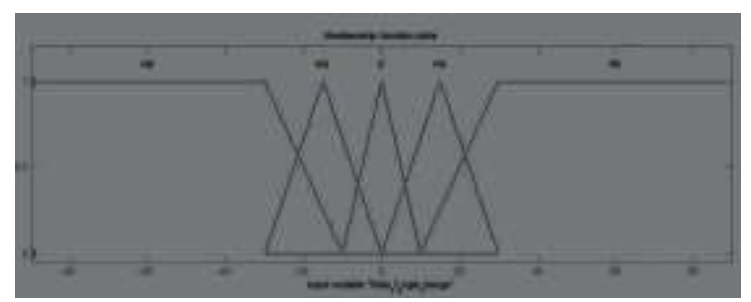

Gambar 5 tingkat input variabel perubahan sudut

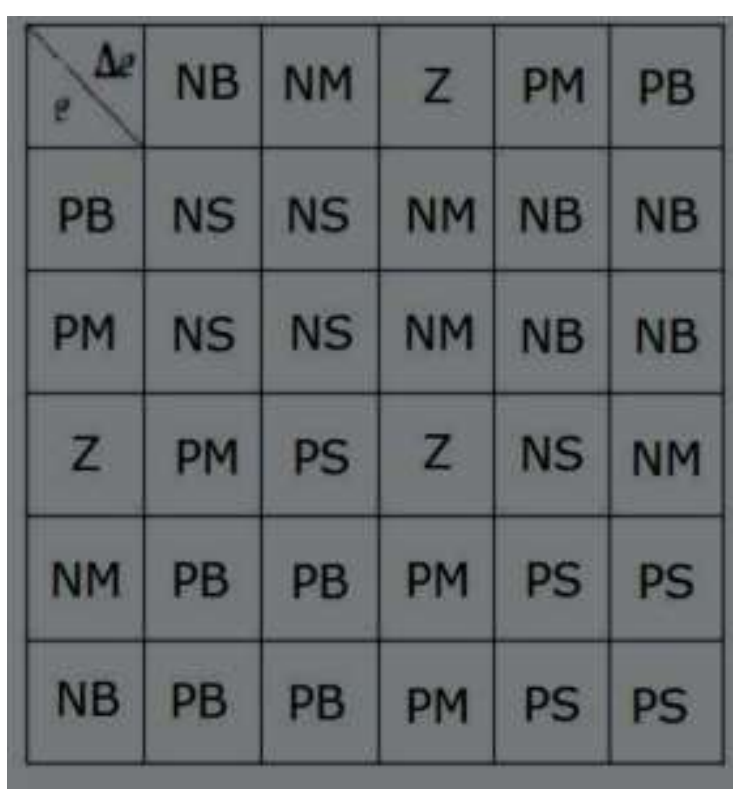

Gambar 6 Aturan Fuzzy

\section{B. Implementasi}

Basis aturan pengontrol juga dirancang berdasarkan pedoman di atas. Pedoman 5, 6 dan 7 menyarankan subset dari basis aturan untuk pengontrol logika fuzzy. Penulis menggunakan 25 aturan dalam basis aturan yang disajikan pada Gambar. 7. Pada Gambar 8 menunjukkan permukaan kontrol yang dihasilkan oleh aturan yang disajikan pada Gambar 7.

Pengontrol fuzzy yang diimplementasikan adalah penggabungan dengan pengontrol posisi PD seperti yang jelas dari Gambar 7 . Kontroler pitch dan yaw axes dirancang dengan cara yang sama seperti roll controller.

Kontroler logika fuzzy dan pemrosesan data sensorik dimodelkan dalam Matlab menggunakan Simulink. Model Simulink. Penulis menggunakan pengontrol fuzzy tipe Mamdani karena merupakan yang paling sederhana dan lebih intuitif khususnya ketika desain pengontrol didasarkan pada seperangkat pedoman yang menggambarkan perilaku

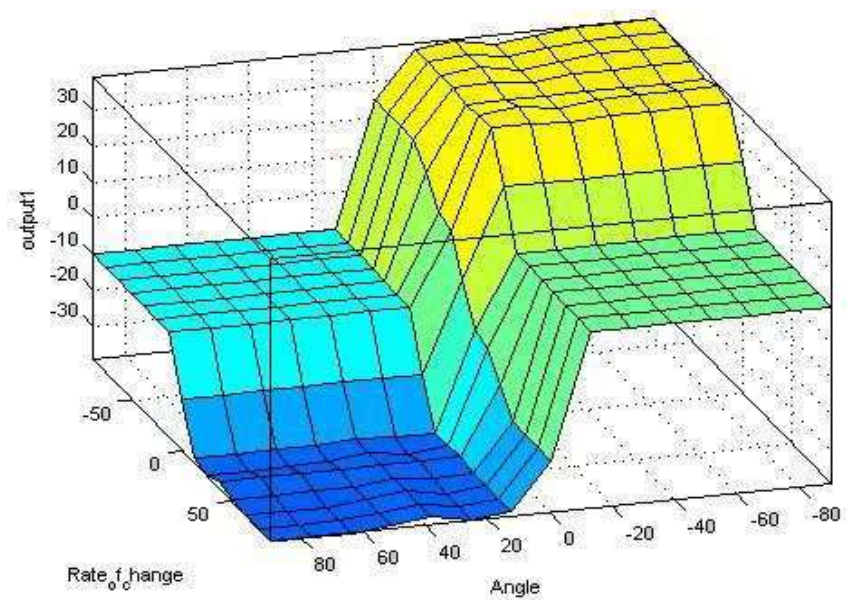


manusia.

\section{HASIL DAN PEMBAHASAN}

Dalam melakukan percobaan awal digunakan quadcopter yang diikan dengan benang sehingga seakan quadcopter tersebut dalam keadaan melayang dan tanpa adanta intervensiterhadap angina dan gangguan lainnya. Kami melakukan percobaan pertama untuk menganalisa berapa banyak waktu yang dibutuhkan quadrocopter untuk menjadi stabil tanpa motor. Hasil percobaan ini ditunjukkan pada Gambar 8.

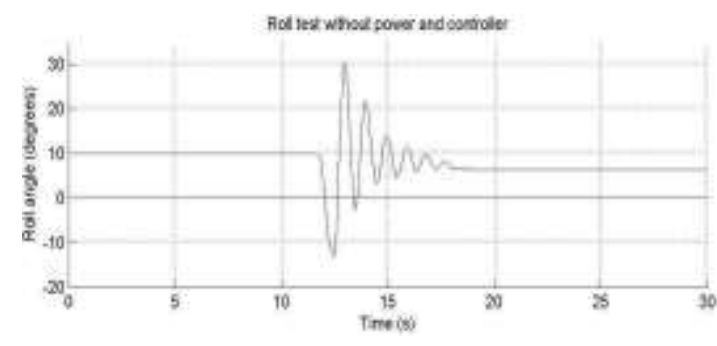

Gambar 8 Waktu stabilisasi tanpa motor i

Pada Gambar 8, ditunjukkan bahwa quadrocopter tidak stabil oleh gaya eksternal pada sekitar 11 detik percobaan. Quadrocopter menjadi stabil setelah sekitar 8 detik. Di sini dapat dilihat bahwa perbedaan antara sudut stabilitas sebelum terjadinya gangguan eksternal dan sesudahnya.

Pergeseran sedikit pada sudut stabilitas untuk quadrocopter ini disebabkan oleh penyesuaian ulang benang yang terkait dengan quadrocopter, seperti yang dinyatakan sebelumnya.

Setelah melakukan percobaan tanpa motor, kami melakukan percobaan dengan motor untuk menganalisis cara kerja kontroler yang baru dirancang untuk menstabilkan quadrocopter dalam pengaturan eksperimen terbatas kami. Hasil percobaan ini ditunjukkan pada Gambar 9.

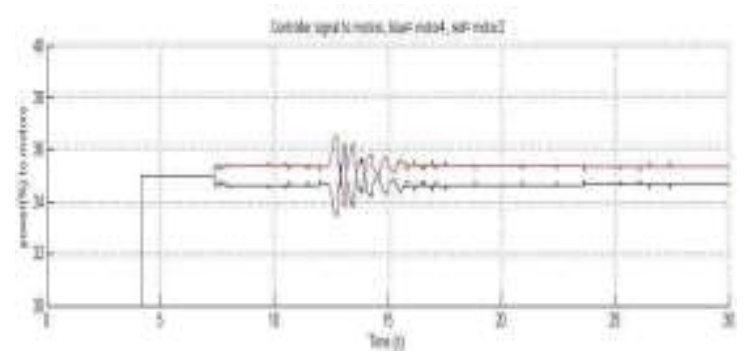

Gambar 9 Uji gangguan dengan daya 35 persen dan gain pengontrol 1
Pada Gambar 9 terlihat bahwa ketika percobaan dimulai, sudut gulungan quadrocopter sekitar -4 derajat, berarti quadrocopter itu miring -4 derajat ke arah motor 2. Pada sekitar detik ke-4 percobaan motor dimulai dengan kekuatan 35 persen. Kontroler dimulai sekitar 7 detik. Aktivitas motor dapat dilihat pada grafik kedua Gambar 9, pada garis merah mewakili sinyal power plus controller ke motor 2 dan garis biru mewakili sinyal power plus controller ke motor 4.

Pada sekitar 13 detik kami mengganggu quadrocopter sepanjang sumbu roll ke 32 derajat. Setelah itu pengontrol menstabilkan quadrocopter dalam waktu kurang dari 4 detik yang merupakan setengah dari waktu yang dibutuhkan dalam percobaan terakhir.

Garis merah pada grafik pertama dari Gambar 9 menunjukkan titik setel untuk sudut gulungan. Pengontrol harus menstabilkan quadrocopter pada set point. Tetapi dapat dilihat pada Gambar 9 bahwa sudut gulungan tidak pernah mencapai titik setel. Di sisi lain, kita lihat pada grafik kedua Gambar 9 bahwa pengontrol terus mencoba untuk mengatasi kesalahan dengan meningkatkan kecepatan motor 2 dan dengan mengurangi kecepatan motor 4, tetapi tetap sudut roll tetap tidak berubah. Ini karena keterbatasan yang terkait dengan pengaturan eksperimen kami. Dengan dua motor kita tidak dapat melakukan percobaan dengan kecepatan motor yang tinggi, karena torsi yang dihasilkan oleh dua motor membuat seluruh pengaturan menjadi tidak stabil. Dan pada kecepatan motor yang lebih rendah kita membutuhkan penguatan controller yang tinggi untuk menstabilkan quadrocopter pada set point. Dan ketika kita menggunakan gain controller yang lebih tinggi, itu menghasilkan osilasi yang tidak terkendali.

Setelah melakukan beberapa percobaan dengan pengaturan daya dan gain pengendali yang berbeda, kami menemukan bahwa motor yang beroperasi dengan daya 35 persen dengan gain pengendali 1 menghasilkan kinerja terbaik untuk pengaturan eksperimental kami yang terbatas. Untuk menemukan pengaturan ini, kami melakukan beberapa percobaan. Kami mulai dari pengaturan daya rendah ke tinggi, dengan nilai yang berbeda untuk mendapatkan.

Gambar 10 menunjukkan hasil untuk daya 15 persen dan gain pengontrol sama dengan 1. 
Karena ini adalah eksperimen yang paling awal, kami tidak dapat mengklasifikasikannya sebagai baik atau buruk.

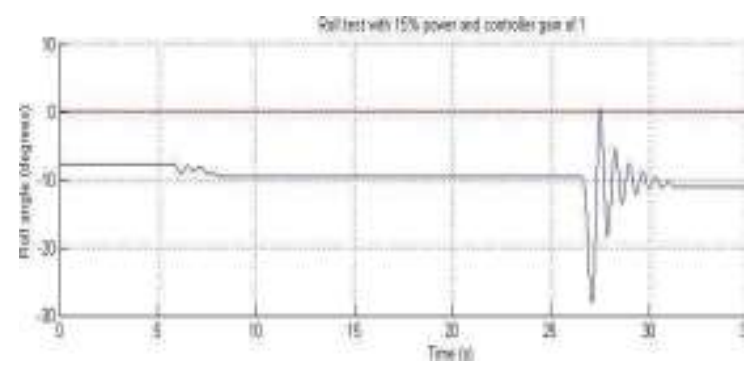

Gambar 10 Uji gangguan dengan daya 15 persen dan gain pengontrol 1

Dengan membandingkan hasil percobaan yang dilakukan pada daya 15 persen dengan nilai gain pengontrol yang berbeda, kami menemukan bahwa gain yang lebih tinggi pada pengaturan daya yang lebih rendah menyebabkan osilasi yang lebih tinggi dan lebih banyak. Kemudian kami meningkatkan daya hingga 25 persen dan menguji pengontrol kami dengan gain sama dengan 1 . Hasil untuk percobaan ini ditunjukkan pada Gambar 11.

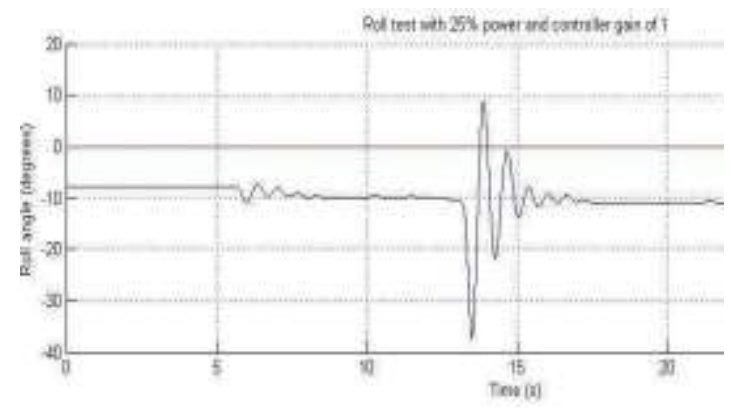

Gambar 11 Uji gangguan dengan daya 25 persen dan gain pengontrol 1

Kemudian kami melakukan percobaan dengan pengaturan daya yang sama tetapi dengan nilai gain pengontrol yang berbeda. Eksperimen yang ditunjukkan pada Gambar 11 dilakukan dengan daya 25 persen dengan nilai gain pengontrol sama dengan 2. Kemudian kami melakukan percobaan lain dengan pengaturan daya yang sama 25 persen dengan nilai gain pengontrol sama dengan 2,5. Kami melihat tren yang sama dengan kekuatan 25 persen seperti yang kami perhatikan pada 15 persen. Tetapi kami menemukan bahwa secara keseluruhan kinerja sistem dengan 25 persen lebih baik daripada kinerja dengan power 15 persen.

\section{KESIMPULAN}

Eksperimen untuk memvalidasi fungsi pengontrol yang telah dirancang mendapat hasil yang memuaskan. Dengan menganalisis hasil kami menyimpulkan bahwa adalah mungkin untuk mengontrol quadrocopter dengan pengontrol fuzzy. Namun, sekarang tidak mungkin membandingkan hasil kami dengan pendekatan kontrol lain yang ada karena eksperimen dilakukan dalam pengaturan yang sangat terbatas. Tidak ada jaminan bahwa pengontrol yang dirancang optimal. Kami sangat percaya bahwa penyempurnaan lebih lanjut akan diperlukan setelah masalah harware diperbaiki.

\section{Daftar Pustaka}

https://www.sparkfun.com/datasheets/Compon ents/HMC6352.pdf.

http://coecsl.ece.illinois.edu/ge423/datasheets/ ADXRS300EB_0.pdf

http://www.arduino.cc.

Saikh Muhammad. 2011, "Quadrocopter Fuzzy Flight Controller", Tesis, Department of Technology at Örebro University.

https://github.com/cemot/autonomous-fuzzyquadcopter.

Zadeh, Lotfi A. 1965,"Fuzzy Set", Journal Information and Control, volume 8, p.338353 